\title{
RESTORATION AND STRENGTHENING SURFACING OF PARTS OF DIE EQUIPMENT
}

\author{
E.A. SOLOMKA ${ }^{1}$, A.I. LOBANOV ${ }^{1}$, L.N. ORLOV $^{2}$, A.A. GOLYAKEVICH ${ }^{2}$ and A.V. KHILKO ${ }^{2}$ \\ ${ }^{1}$ Company «Energomashspetsstal» \\ 15 Sovkhoznaya Str., 84306, Kramatorsk, Donetsk oblast, Ukraine \\ ${ }^{2}$ TM.VELTEK Ltd. \\ 15 Bozhenko Str., 03690, Kiev, Ukraine. E-mail: office@veltec.ua
}

\begin{abstract}
The results of works on increase of life of fixture of forging-press equipment by application of electric arc surfacing using electrodes and flux-cored wires are given. It is preferably to create and apply the specialized flux-cored wires, providing high life of deposited metal by optimization of its alloying. It is shown that application of restoration surfacing considerably increases the cycle between the repairs during operation of press strikers and provides economic effect of equipment service. 8 Ref., 5 Figures.
\end{abstract}

$\boldsymbol{K} \boldsymbol{e} \boldsymbol{y} \boldsymbol{w} \boldsymbol{O} \boldsymbol{d} \boldsymbol{s}:$ arc surfacing, parts of die equipment, restoration and strengthening, flux-cored wire, extension of life

In forging-press workshop of the Company «Energomashspetsstal» the repair and manufacture of fixture for different types of forging-press operations including strikers are constantly carried out. To increase the life and minimize the terms of repair of tools, the analysis of application of existing surfacing materials in surfacing of strikers was carried out basing on the condition of providing combination of price and tool life [1-7].

The repair of tools of forging-press equipment using surfacing is efficient due to a lower price as compared to the purchase of a new part. Dies and strikers for hot stamping and forging, pressmould and die casting undergo thermal shocks, high specific pressures, abrasion wear, which result in formation of cracks, burrs and hairlines, loss of geometry of working surfaces of parts.

During selection of surfacing material as applied to the repair of dies of hammer heads and high-speed presses, the metal should have a complex of properties depending on the conditions of contact with hot metal. Under the conditions of quick deformation the ductility, resistance to flame erosion and plastic deformation are determining. Under the conditions of slow deformation the increased requirements to heat and oxidation resistance are additionally specified [8].

In the present work the peculiarities of technology of repair surfacing of plane striker and plane insert of steel $5 \mathrm{KhNM}$ are studied ( $\mathrm{Fi}^{-}$ gure 1).

This type of fixture is quite intensively used in the press of 31.5 MN force for manufacture of the frequently varied nomenclature of products, which results in its quick local wear. After wear of working surface and formation of overlaps of metal, strikers and inserts are subjected to regrinding of working part of about $70 \mathrm{~mm}$ thickness on average.

For repair of tools the application of three variants of surfacing using electrodes of different type of alloying (KhN65MV; Stelloy C-O, Stelloy Ni520-G and OZSh-1, OZSh-6) was considered.

After preliminary study of characteristics and peculiarities of application of these consumables the preference was given to the electrodes OZSh1 and OZSh-6, as far as they do not require application of special equipment and their cost is

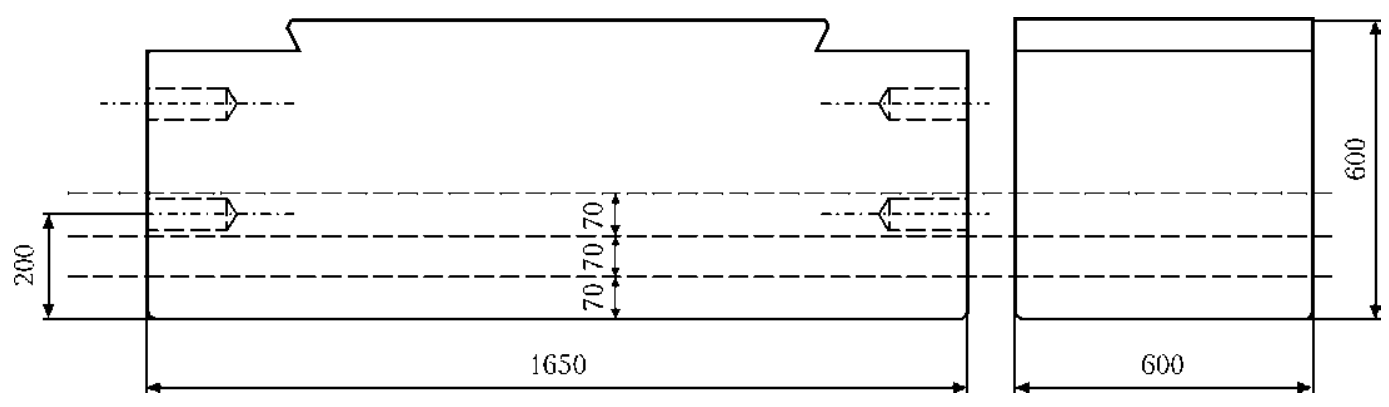

Figure 1. Press striker of $31.5 \mathrm{MN}$ force 


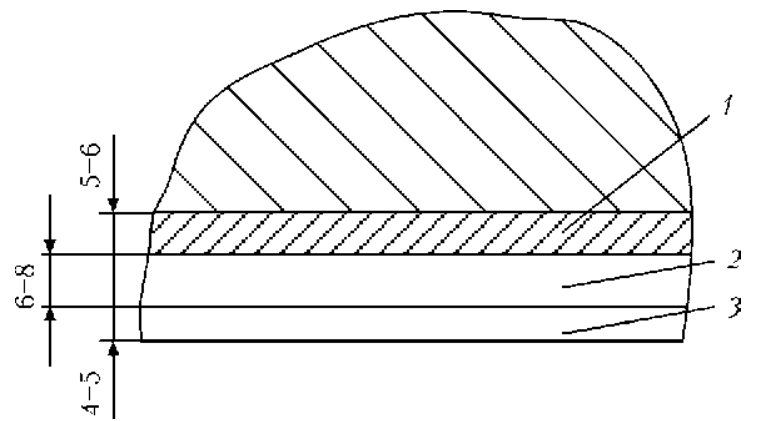

Figure 2. Scheme of location of deposited layers: 1 sublayer; 2 - interlayer; 3 - working layer

lower. The surfacing was performed with preheating of strikers to $300-400{ }^{\circ} \mathrm{C}$ simultaneously by two gas-air torches. Surfacing of striker and insert was performed in three layers (Figure 2): sublayer - using wire Sv-08G2S; interlayer electrodes OZSh-1; working layer - electrodes OZSh-6.

After each pass the peening of deposited layer was carried out. After completion of surfacing the strikers were put to the furnace for tempering at $580{ }^{\circ} \mathrm{C}$. The temperature of preheated furnace was $400{ }^{\circ} \mathrm{C}$, time of soaking was $3 \mathrm{~h}$, rate of furnace heating and cooling was $50{ }^{\circ} \mathrm{C} / \mathrm{h}$.

The deposited striker and insert passed verification in the press of $31.5 \mathrm{MN}$ force in the forging press workshop. The comparison of life of non-deposited tool and deposited one showed the following:

- non-deposited striker was used in work since 23.11.2011 till 25.01.2012 and allowed forging of $781.7 \mathrm{t}$ with the norm of consumption of $5.7 \mathrm{~kg} / \mathrm{t}$, and the working area of a striker required regrinding;

- deposited striker was used since 25.01.2012 till 07.05.2012 and allowed forging of $2201.13 \mathrm{t}$ with the norm of consumption of $2.1 \mathrm{~kg} / \mathrm{t}$, which allowed 2.8 times increasing of the tool life ( $\mathrm{Fi}^{-}$ gure 3 ).

In both cases in the working zone of the striker a wear appeared (Figure 4), which was eliminated by surfacing of this area and further treatment of a striker.

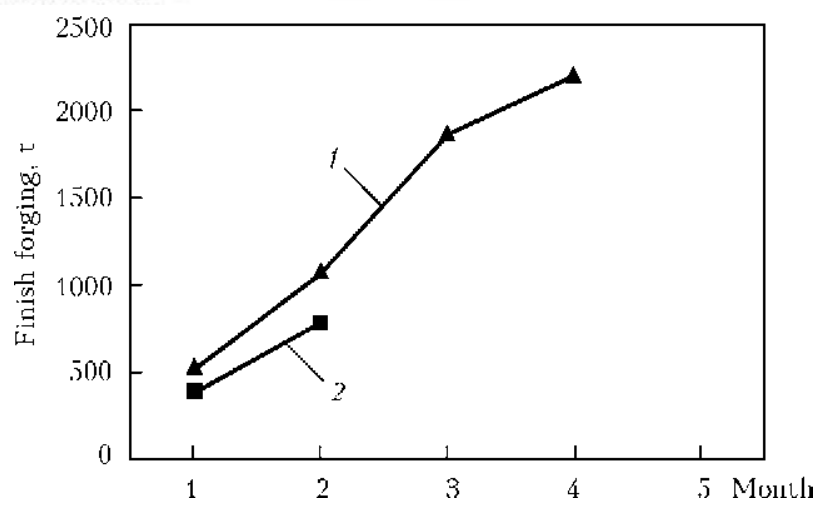

Figure 3. Life of deposited (1) and non-deposited (2) press striker

The economic effect at 21,000 t/year average finish forging in the press of $31.5 \mathrm{MN}$ force amounted to $98,700 \mathrm{UAH}$.

For restoration and strengthening surfacing of both the worn out parts of dies (punches, moulds manufactured of tool steels $5 \mathrm{KhGM}$, $5 \mathrm{KhNV}, 5 \mathrm{KhNM}, 7 \mathrm{Kh} 3, \mathrm{U} 10 \mathrm{~A}$, etc.) as well as the new ones manufactured of tool and structural grades of steels (45, St5, etc.), the enterprise TM.VELTEK Ltd developed flux-cored wires VELTEK-N460.01, VELTEK-N460.04, VELTEK-N460.05 instead of electrodes TsSh-1 (30V8Kh3), Sh-1, Sh-16, TsN-4 (35G6), TsN-5, NZh-2, NZh-3 (GOST 10051-62).

The system of alloying of flux-cored wires is based on the optimization of deposited metal alloying with carbon, silicon, manganese, nickel, chromium, molybdenum, vanadium, tungsten and titanium, due to which the obtaining of lowcarbon martensite matrix, strengthened with disperse carbides and intermetallics, in deposited metal is provided.

The metal deposited by flux-cored wires VELTEK-N460.01 (HRC 38-45) and VELTEKN460.05 (HRC 48-54), is characterized by a high wear resistance under the conditions of operation of dies for cold and hot deformation of metals and satisfactory resists to high pressure and shocks. For surfacing of spots in the grooves of a die, requiring high hardness and wear resistance of strikers of forging-press equipment, it is recommended to use the wire VELTEK-N460.05.

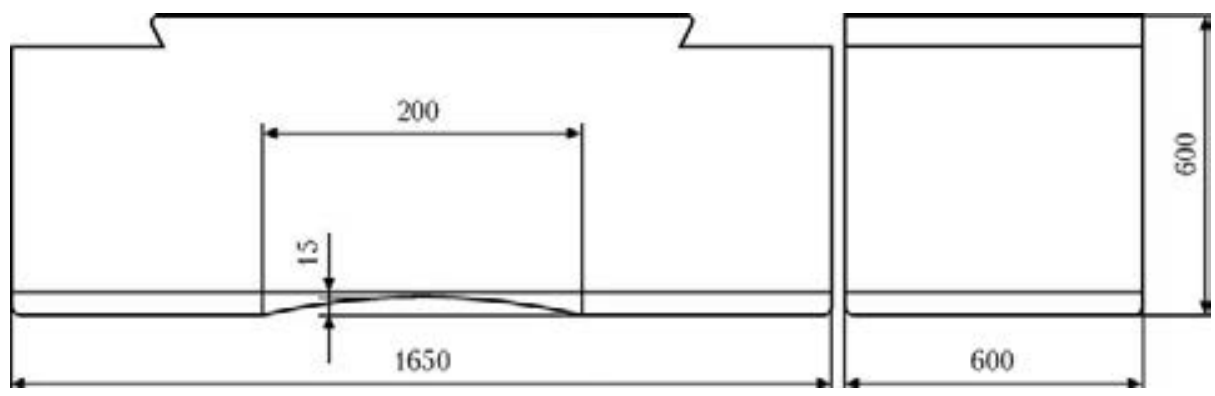

Figure 4. Wear of working surface of press striker 
As applied to strengthening and repair of parts of dies of steels $5 \mathrm{KhNM}, 5 \mathrm{KhNV}, 38 \mathrm{KhN} 3 \mathrm{M}-\mathrm{BA}$ for pressing the billets of copper, brass L63, alloys ShV15-1, it is preferable to apply the wire VELTEK-N460.04 (HRC 48-54). The deposited metal has an increased resistance to «sticking» of billet with the die working surface. The surfacing is performed at direct current of reverse polarity with shielding in mixture of gases $\mathrm{Ar}+$ $+18 \% \mathrm{CO}_{2}$.

The wire VELTEK-N460.01 was also successfully applied for repair of dies of production of crankshafts and connecting rods of engines of the automobiles «KamAZ» (Naberezhnye Chelny, RF) (Figure 5).

The dies, subjected to surfacing, were exposed to annealing, defective spots were cleaned, cracks were eliminated using milling and chamfers in the grooves were removed for surfacing. The defective spots were milled, and in some cases were simply cleaned using abrasive tool, but without sharp transitions. All the chamfers and grooves after treatment using any method had roundings with radius of not less than $3 \mathrm{~mm}$. The angle of groove removal of cracks is not less than $40^{\circ}$, and width of the bottom was not less than $9 \mathrm{~mm}$.

During repair of spots with cracks, after preparation of crack for surfacing the groove bottom was filled using wire VELTEK-N252-M with the next surfacing by wires VELTEK-N460.01 or VELTEK-N460.05. The dies prepared for surfacing were preheated to $350-400{ }^{\circ} \mathrm{C}$ to prevent initiation of cracks during surfacing. The craters were melted by short arc with minimum penetration and sharp interruption of arc. The dies, requiring treatment of working surfaces by cutting tool, immediately after surfacing were subjected to annealing $\left(900{ }^{\circ} \mathrm{C}\right.$ during $2 \mathrm{~h}$, furnace cooling). The annealing after slow cooling of parts is admitted. After annealing the mechanical treatment of dies and their next hardening and tempering were carried out.

The experience of application of flux-cored wires VELTEK-N460.01 and VELTEK-N460.05 showed that increase in efficiency of striker, inserts and dies is achieved by increase in efficiency of surfacing process, decrease of costs for additional time and especially by decrease in consumption of surfacing material. Consumption of electrodes per $1 \mathrm{~kg}$ of deposited metal amounts to $1.8 \mathrm{~kg}$ and that for flux-cored wire is $1.17 \mathrm{~kg}$, at almost equal price of surfacing material.
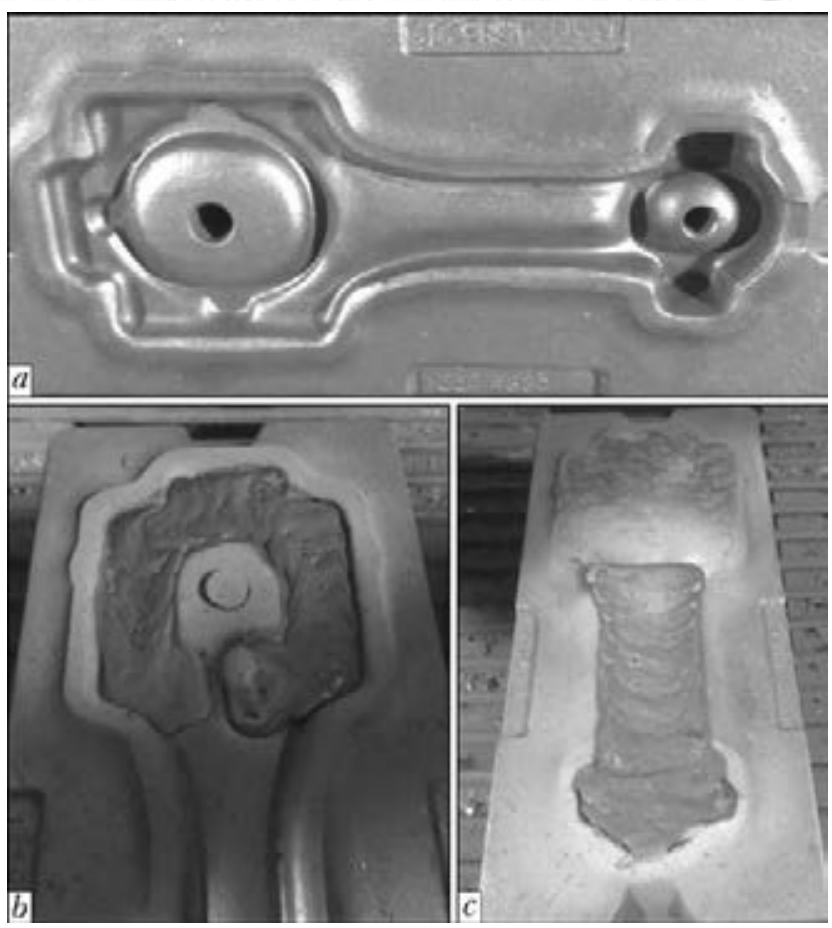

Figure 5. Repair of die part (connecting rod): $a-$ condition of worn-out working surface of die; $b$ - bead surfacing without oscillations; $c$ - surfacing with oscillations

\section{Conclusion}

1. The application of semi-automatic electric arc surfacing reduces man-hours during repair of fixture for forging-press equipment and increases the duration of cycle between repairs.

2. The application of flux-cored wire allows increasing the efficiency of surfacing works more than 1.5 times.

1. Atroshenko, A.P. (1971) Increase in service life of hot pressing dies. Leningrad: Metallurgiya.

2. Velsky, E.I. (1973) Wear of die and means of increase in its life. Kuzn.-Shtamp. Proizvodstvo, 3, 1-3.

3. GOST 10543-98: Steel surfacing wire. Technical requirements. Introd. 01.01.2001.

4. GOST 10051-75: Metal coated electrodes for manual arc deposition of surface layers with special properties. Types. Introd. 01.01.1977

5. (1979) Surfacing materials of CIS countries: Catalogue. Kiev-Moscow: MTsMTI.

6. Ryabtsev, I.A., Zhudra, A.P., Kirilyuk, G.A. et al. (2007) Surfacing flux-cored wires developed in PWI. Svarshchik, 1, 30-32.

7. Kondratiev, I.A., Ryabtsev, I.A. (2009) Surfacing of stamping tool for hot deformation of metal by maraging steel layer. Ibid., 4, 6-7.

8. Geller, Yu.A. (1983) Tool steels. Moscow: Metallurgiya.

Received 21.03.2014 